\title{
Partial Validation of High Performance Liquid Chromatography for Analysis of Isoniazid in Rat Plasma
}

\section{(Validasi Parsial Kromatografi Cair Kinerja Tinggi untuk Analisis Isoniazid pada Plasma Tikus)}

\author{
NOVI YANTIH ${ }^{1 *}$, SITI HAFILAH ${ }^{1}$, YAHDIANA HARAHAP ${ }^{2}$, WAHONO \\ SUMARYONO ${ }^{1}$, RIANTO SETIABUDY $^{3}$ \\ ${ }^{1}$ Pharmacy Faculty, University of Pancasila, Jakarta, Indonesia
${ }^{2}$ Pharmacy Faculty, Universitas Indonesia, Depok, Indonesia
${ }^{3}$ Medical Faculty, Universitas Indonesia, Jakarta, Indonesia
}

Diterima 21 Januari 2018, Disetujui 25 Februari 2018

\begin{abstract}
Tuberculosis is an infectious disease caused by Mycobacterium tuberculosis. Nicotinic acid derivatives such as isoniazid have the strongest anti-tuberculosis properties. For pharmacokinetics studying of isoniazid (INH), a method is needed to determine the levels of INH in plasma. The aim of this research is to partial validate of high performance liquid chromatography (HPLC) for analysis of INH in rat plasma.For the preliminary study, rat plasma was used. The HPLC system used is a stationary phase $\mathrm{C} 18$ with length $250 \mathrm{~mm}$ and temperature of $30^{\circ} \mathrm{C}$, mobile phase hexane sulphonate acid $20 \mathrm{mM}$ $\mathrm{pH}$ 2.47-methanol (65:35). The analytical parameters in partial validated were linearity, lower limit of quantification (LLOQ), precision, accuracy, and recovery. The results of linearity test of INH showed $\mathrm{r}$ value of 0.9996 . LLOQ of this methodwas $0.1258 \mu \mathrm{g} / \mathrm{mL}$. The resulting accuracy and precision value met FDA requirements with a percent recovery ranging from $96.57-107.99 \%$. The HPLC system was a valid method for analysis of INH in rat plasma.
\end{abstract}

Keywords: Isoniazid, high performance liquid chromatography, rat plasma, partial validation.

\begin{abstract}
Tuberkulosis adalah penyakit infeksi yang disebabkan oleh Mycobacterium tuberculosis. Turunan asam nikotinat seperti isoniazid memiliki sifat anti-tuberkulosis terkuat. Untuk studi farmakokinetik isoniazid (INH), diperlukan metode untuk menentukan kadar INH dalam plasma. Tujuan dari penelitian ini adalah untuk melakukan validasi parsial dari kromatografi cair kinerja tinggi (HPLC) untuk analisis INH dalam plasma tikus. Untuk studi pendahuluan, digunakan plasma tikus. Sistem HPLC yang digunakan adalah fase stasioner $\mathrm{C} 18$ dengan panjang $250 \mathrm{~mm}$ dan suhu $30{ }^{\circ} \mathrm{C}$, fase gerak asam heksana sulfonat $20 \mathrm{mM} \mathrm{pH}$ 2,47- metanol (65:35). Parameter analitik yang divalidasi parsial adalah linearitas, batas kuantifikasi lebih rendah (LLOQ), presisi, akurasi, dan pemulihan. Hasil uji linieritas INH menunjukkan nilai $r=0,9996$. LLOQ dari metode ini adalah $0,1258 \mu \mathrm{g} / \mathrm{mL}$. Akurasi yang dihasilkan dan nilai presisi memenuhi persyaratan FDA dengan persen pemulihan mulai dari 96,57-107,99\%. Sistem HPLC adalah metode yang valid untuk analisis INH dalam plasma tikus.
\end{abstract}

Kata kunci: Isoniazid, kromatografi cair kinerja tinggi, plasma tikus, validasi parsial.

\footnotetext{
* Penulis korespondensi, Hp. 08129624502

e-mail: novi_yantih@yahoo.com
} 


\section{INTRODUCTION}

THE World Health Organization (WHO) recently issued a revision of first-line anti-tuberculosis drug dosage recommendations for children ${ }^{(11)}$. Tuberculosis is an infectious disease caused by Mycobacterium tuberculosis. Nicotinic acid derivatives such as isoniazid (INH) has the strongest anti-tuberculosis properties $^{(5)}$. In the absence of pharmacodynamics data for children, and therefore data that demonstrate an association between serum drug concentration and clinical outcome, optimal anti-tuberculosis therapy should aim to produce the targeted serum drug concentrations that have been determined in adult pharmacokinetic and pharmacodynamics studies ${ }^{(9)}$. For pharmacokinetics study of INH, a method is needed to determine the levels of INH in plasma. For the preliminary study, rat plasma was used.

Full validation is necessary when developing and implementing a bioanalytical method for the first time for a new drug entity. In situations where minor changes are made to an analytical method that has already been validated, a full validation may not be necessary, depending on the nature of the applied changes. Changes for which a partial validation may be needed include limited sample volume such as rat plasma $^{(3)}$.

The aim of this research is to partially validate the high performance of liquid chromatography (HPLC) for the analysis of INH in rat plasma. The analytical parameters of the partial validation carried out include linearity, lower limit of quantification (LLOQ), precision, accuracy, and recovery.

One of the most important concerns in developing bio-analytical methods is the ability of the method of analyzing the analyte in the matrix. The ability of this method is indicated by the LLOQ value. According to European Medicines Agency (EMA) on Guideline on bioanalytical method validation, the LLOQ should not be higher than $5 \%$ of the optimal maximum serum drug concentration $\left(\mathrm{C}_{\max }\right)^{(2)}$. For INH, the proposed $\mathrm{C}_{\max }$ for therapy is 3 to $5 \mu \mathrm{g} / \mathrm{mL}^{(6)}$, so the LLOQ value should be less than $0.15 \mu \mathrm{g} / \mathrm{mL}$.

Levels of INH in plasma using high performance liquid chromatography (HPLC) with a gradient elution systems and diode array detectors ${ }^{(1,10)}$ have been determined in previous studies. Other HPLC methods developed for the determination of INH with LLOQ was $0.24 \mu \mathrm{g} / \mathrm{mL}$ using an ion pair chromatography with a gradient elution system, a UV detector at $290 \mathrm{~nm}$, and sample preparation by protein precipitation techniques using tri chloro acetic acid $^{(7)}$. INH has been determined on a reverse phase HPLC system with nicotinic acid as internal standard and extracted of analytes from plasma with acetonitrile as a protein precipitator. The method was less sensitive because it is only capable of detecting INH in the LLOQ region of about $4 \mu \mathrm{g} /$ $\mathrm{mL}^{(8)}$. Existing methods are still less sensitive to detect $\mathrm{INH}^{(4)}$, so a more sensitive HPLC method was needed to be developed.

\section{MATERIAL AND METHOD}

MATERIAL. INH (ZhejiangJiangbeiPharmaceut ical,Zhejiang,China),Vitamin B6, hexane sulphonate, and acetic acid (Merck,Darmstadt, Germany) werepro analysisgrade. Methanol (Merck,Darmstadt, Germany)was pro HPLC grade. The experimental animals used were white male rats (Rattus norvegicus) of the Sprague-Dawley strain that were developed in the Non Ruminansia and Animal Hope Laboratory, Faculty of Animal Science, Bogor Agricultural University. Plasma was obtained from rat blood. The blood samples were collected from rats through the orbital vein in the eyes using a capillary pipe and placed in an Eppendorf tube.

Chromatography System. The HPLC (Shimadzu LC20AD, Kyoto, Japan) system was supported with $\mathrm{C} 18$ (150 $\mathrm{mm} \times 4,6 \mathrm{~mm})$ as stationary phase, hexane sulphonate $20 \mathrm{mM}$ (pH 2.47)-methanol (65:35) as mobile phase, with flow rate of $1 \mathrm{~mL} / \mathrm{min}, \mathrm{UV}$ detector at wavelength of $265 \mathrm{~nm}$, and Vitamin B6 (Vit B6)as an internal standard. The system suitability test was done before analysis.

Sample Preparation. Quality control samples (QCs) were prepared with blank rat plasma in low $(0.5 \mu \mathrm{g} / \mathrm{mL})$, medium $(5 \mu \mathrm{g} / \mathrm{mL})$ and high $(10 \mu \mathrm{g} / \mathrm{mL})$ concentrations. A total of $190 \mu \mathrm{L}$ QCs was inserted into the tube and then added $10 \mu \mathrm{L}$ Vit B6 $2000 \mathrm{ug} /$ $\mathrm{mL}$, and $600 \mu \mathrm{L}$ methanol, then vortexed for 60 seconds and centrifuged at $3500 \mathrm{rpm}$ for 20 minutes. Supernatant was taken and then injected into the chromatogram. This solution was used to optimize the HPLC system, such as concentration of hexane sulphonate, composition and flow rate of mobile phase, and column temperature.

Partial Validation. Determination of Lower Limit of Quantification. The lower limit of quantification (LLOQ) is the lowest concentration of analyte in a sample which can be quantified reliably, with an acceptable accuracy and precision. The sample solution is prepared in the same way on sample preparation. INH was made at concentration of $5 \%$ from Cmax $(3 \mu \mathrm{g} / \mathrm{mL})$ of INH in blood plasma ${ }^{(6)}$. The accuracy and precision of method was tested in this concentration. The mean concentration should be 
within $20 \%$ of the nominal values of the LLOQ. CV value should not exceed $20 \%$ for the $\operatorname{LLOQ}^{(2,3)}$.

Calibration Standard. The calibration standards were prepared in the same matrix as the matrix of the intended study samples by spiking the blank matrix with known concentrations of the analyte. There is one calibration curve for each analyte studied in the method validation and for each analytical run. Preparation of calibration curve is done by using a blank sample (plasma matrix), zero sample (contain internal standardin plasma), and sample solution with various concentration. This range covered by the calibration curve range, defined by the LLOQ being the lowest calibration standard and the upper limit of quantification (ULOQ), being the highest calibration standard ${ }^{(2,3)}$. The preparation was the same as sample simulation preparation for optimizing the HPLC system.

Accuracy. Accuracy was assessed on samples spiked with known amounts of the analyte, the quality control samples (QCs). Within-run accuracy was determined by analyzing in a single run a minimum of 5 samples per level at a minimum of 4 concentration levels which are covering the calibration curve range: the LLOQ, within three times the LLOQ (low QC), around $30-50 \%$ of the calibration curve range (medium QC), and at least at $75 \%$ of the upper calibration curve range (high QC). The mean concentration should be within $15 \%$ of the nominal values for the QC samples

Precision. The precision of the analytical method describes the closeness of repeated individual measures of analyte. Precision is expressed as the coefficient of variation (CV). Precision should be demonstrated for the LLOQ, low, medium and high QC samples, within a single run and between different runs. For the validation of the within-run precision, there should be a minimum of five samples per concentration level at LLOQ, low, medium and high $\mathrm{QC}$ samples in a single run. The within-run $\mathrm{CV}$ value should not exceed $15 \%$ for the QC samples.

Recovery. Recovery experiments were performed by comparing the analytical results for extracted samples at three QC samples in low, medium, and high concentrations.

\section{RESULT AND DISCUSSION}

Chromatography System. Based on the result, the optimum conditions for determining of INH in rat plasma was done by using C18 $(150 \mathrm{~mm} \times 4.6 \mathrm{~mm})$ as stationary phase, hexanesulphonate $20 \mathrm{~mm}(\mathrm{pH}$ 2.47)-methanol (65:35) as mobile phase, with flow rate of $1 \mathrm{~mL} / \mathrm{min}$, UV detector at $265 \mathrm{~nm}$, and Vit B6 as an internal standard. The resolution obtained between INH and unknown peak was 1.508. The tailing factor for INH and Vit B6 were 1.160 and 0.911, respectively.

The selectivity of method was described in the resolution, that was higher than 1.5 and tailing factor of the analyte was under 1.2. The $\mathrm{K}$ value was 1.3260 , and $\mathrm{N}$ high values indicate good separation efficiency. One of the advantages of this high performance liquid chromatography (HPLC) system was to have a running time under 10 minutes (Figure 1).
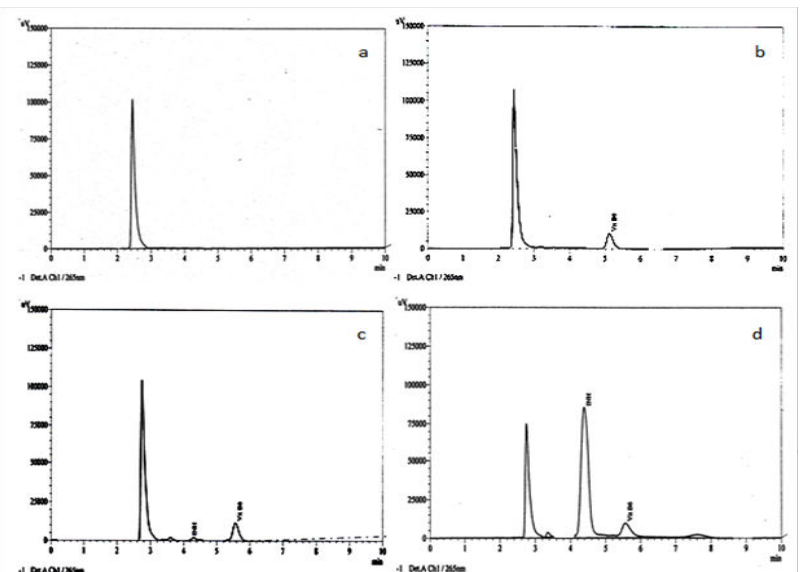

Figure 1. Chromatogram of Blank Plasma (a), Zero Sample (b), Quality Control (QC) Sample in Lower Limit of Quantification Concentration (c), and QC Sample in High Concentration (d) in Rat Plasma In Vitro by High Performance Liquid Chromatography.

Partial Validation. Calibration Curve. The calibration curve is used to describe the response and the concentrations are linear. Response was good when the value of coefficient correlation ( $\mathrm{r}$ ) closed to 1. Calibration curve of INH met good linearity with $r$ value of INH was 0.9950 (Figure 2). Thus, it can be concluded that the method produces a linear response to the concentrations of INH.

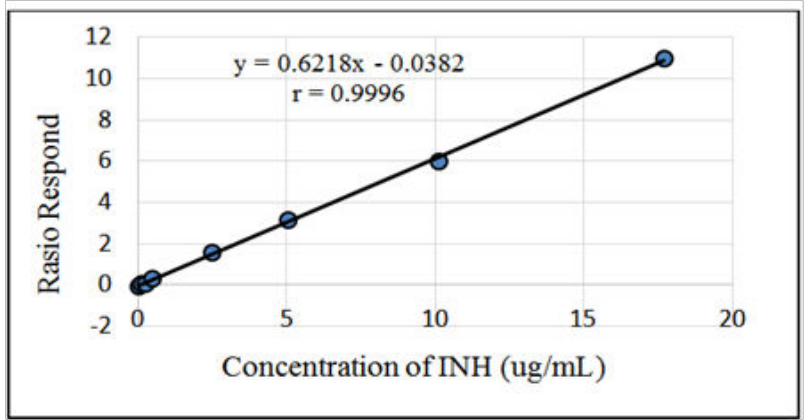

Figure 2. Calibration Curve of Isoniazid (INH)

Lower Limit of Quantification. Lower limit of quantification (LLOQ) of the high performance liquid chromatographymethod for INH was $0.1258 \mu \mathrm{g} / \mathrm{mL}$ 
(Table 1). The results show that the sensitive method for analysis INH in rat plasma because LLOQ was less than $1 / 20$ from $\mathrm{C}_{\text {max }}{ }^{(2)}$ of INH $(3 \mu \mathrm{g} / \mathrm{mL})^{(6)}$. LLOQ of this method was more sensitive than previous method (Table 2).

Table 1.Lower Limit of Quantification Result of Analysis Method of Isoniazid by High Performance Liquid Chromatography.

\begin{tabular}{|c|c|c|c|c|c|c|c|c|}
\hline \multirow[b]{2}{*}{$\begin{array}{c}\text { Actual } \\
\text { value of } \\
\text { Isonizid } \\
\text { ( } \mu g \mathrm{~mL})\end{array}$} & \multicolumn{2}{|c|}{ Area } & \multirow[b]{2}{*}{$\begin{array}{l}\text { Ratio } \\
\text { Respond }\end{array}$} & \multicolumn{5}{|c|}{ Measured Value } \\
\hline & Isoniazid & $\begin{array}{l}\text { Intemal } \\
\text { Standard }\end{array}$ & & $\begin{array}{c}\text { Measurued } \\
\text { Value } \\
(\mu g / m L)\end{array}$ & $\begin{array}{c}\text { Mean of } \\
\text { Value } \\
(\mu \mathrm{g} / \mathrm{mL})\end{array}$ & $\begin{array}{l}\text { Standard } \\
\text { Deviation }\end{array}$ & $\begin{array}{l}\text { Coefficient } \\
\text { of } \\
\text { Variation } \\
(\%)\end{array}$ & $\begin{array}{c}\text { Differentiation } \\
(\%)\end{array}$ \\
\hline \multirow{5}{*}{0.1258} & 6011 & 125107 & 0.0480 & 0.1105 & & & & 12.13 \\
\hline & 6006 & 126613 & 0.0474 & 0.1099 & & & & 12.61 \\
\hline & 5992 & 124725 & 0.0480 & 0.1105 & 0.1099 & 0.0011 & 1.02 & 12.13 \\
\hline & 5988 & 124440 & 0.0481 & 0.1106 & & & & 12.07 \\
\hline & 6048 & 132972 & 0.0455 & 0.1079 & & & & 14.16 \\
\hline \multirow{5}{*}{0.2515} & 14948 & 122326 & 0.1222 & 0.2590 & & & & 2.96 \\
\hline & 14545 & 129996 & 0.1119 & 0.2424 & & & & -3.63 \\
\hline & 14255 & 120211 & 0.1186 & 0.2531 & 0.2521 & 0.0073 & 2.89 & 0.65 \\
\hline & 14488 & 126027 & 0.1150 & 0.2473 & & & & -1.67 \\
\hline & 14895 & 121907 & 0.1222 & 0.2589 & & & & 2.95 \\
\hline
\end{tabular}

Table 2. The Comparison of Lower Limit of Quantification (LLOQ) and Retention Time of Isoniazid Between This Research and Previous Method

\begin{tabular}{clcc}
\hline No & \multicolumn{1}{c}{ Method of } & $\begin{array}{c}\text { LLOQ } \\
(\mu \mathrm{g} / \mathrm{mL})\end{array}$ & $\begin{array}{c}\text { Retention } \\
\text { Time (minute) }\end{array}$ \\
\hline 1 & Unsalam et al. (2005) & 0.60 & 3.8 \\
2 & Stella (2011) & 4.74 & 11.7 \\
3 & Segovia et al. (2007) & 0.50 & 4.5 \\
4 & Bhandari and Kaur (2012) & 0.20 & 3.5 \\
5 & This Research (2017) & 0.16 & 4.4 \\
\hline
\end{tabular}

Accuracy and Precision. The accuracy and precision tests were carried out at 3 concentrations: the quality control (QC) samples at low concentrations $(0.5030 \mu \mathrm{g} / \mathrm{mL})$, medium $(5.0302 \mu \mathrm{g} / \mathrm{mL})$, and height $(10.0604 \mu \mathrm{g} / \mathrm{mL})$. QC samples were not be freshly prepared, but were frozen and treated the same way as for the analysis of study samples. The QC samples were spiked independently from the calibration standards, using separately prepared stock solutions, unless the nominal concentrations of the stock solutions have been established.

The accuracy of an analytical method describes the closeness of the determined value obtained by the method to the nominal concentration of the analyte (expressed in percentage). The differentiation of measured value was within $15 \%$ of the nominal values for the QC samples. The result showed that the differentiation values were $0.47-7.95 \%$ (Table 3 ).
The precision of the analytical method describes the closeness of repeated individual measures of analyte. Precision is expressed as the coefficient of variation (CV). The result showed that the CV values were $1.91-2.39 \%$ (Table 3 ). This proposed method met the accuracy and precision according to FDA (2013) and EMA (2012).

Table 3. Accuracy and Precision of the proposed high performance liquid chromatography

\begin{tabular}{ccccccc}
\multicolumn{6}{c}{ performance liquid chromatography } & . \\
\hline $\begin{array}{c}\text { Actual } \\
\text { value of } \\
\text { Isoniazid } \\
(\mu \mathrm{g} \mathrm{mL})\end{array}$ & $\begin{array}{c}\text { Measured } \\
\text { Value } \\
(\mu \mathrm{g} \mathrm{mL})\end{array}$ & $\begin{array}{c}\text { Mean of } \\
\text { Value } \\
(\mu \mathrm{g} \mathrm{mL})\end{array}$ & $\begin{array}{c}\text { Standard } \\
\text { Deviation }\end{array}$ & $\begin{array}{c}\text { Coefficient } \\
\text { of Variation } \\
(\%)\end{array}$ & $\begin{array}{c}\text { Differentiation } \\
(\%)\end{array}$ & $\begin{array}{c}\text { Recovery } \\
(\%)\end{array}$ \\
& 0.4770 & & & & 5.18 & 105.47 \\
& 0.4845 & & & & 3.68 & 103.82 \\
0.5030 & 0.4764 & 0.4801 & 0.0115 & 2.39 & 5.29 & 105.58 \\
& 0.4968 & & & & 1.24 & 101.25 \\
& 0.4658 & & & & 7.40 & 107.99 \\
\hline \multirow{5}{*}{5.0302} & 5.1712 & & & & 2.80 & 97.27 \\
& 5.2089 & & & & 3.55 & 96.57 \\
& 5.1410 & 5.1395 & 0.0579 & 1.13 & 2.20 & 97.85 \\
& 5.1225 & & & & 1.83 & 98.20 \\
& 5.0540 & & & & 0.47 & 99.53 \\
\hline \multirow{5}{*}{10.0604} & 9.5875 & & & & 4.70 & 104.93 \\
& 9.2602 & & & & 7.95 & 108.64 \\
& 9.7265 & 9.4798 & 0.1806 & 1.91 & 3.32 & 103.43 \\
& 9.3933 & & & & 6.63 & 107.10 \\
& 9.4316 & & & & 6.25 & 106.67 \\
\hline
\end{tabular}

Recovery. The absolute recovery of INH was calculated for replicate spiked quality control (QC) samples $(0.5030,5.0302$, and $10.0604 \mu \mathrm{g} / \mathrm{mL})$. Extraction recovery is calculated by comparing the peak area ratios of INH in spiked samples and INH standard respectively at QC concentrations. Results show an overall mean percent recovery of 96.57$107.99 \%$ (Table 3). According to FDA (2013), recovery pertains to the extraction efficiency of an analytical method within the limits of variability. It is stated that recovery of the analyte need not be $100 \%$, but the extent of recovery of an analyte and of the internal standard should be consistent, precise, and reproducible. Hence the method developed and reported presently though showing a recovery of above $96 \%$ may be considered suitable taking into account the consistency and reproducibility of the results obtained upon repetitive evaluation ${ }^{(3)}$.

\section{CONCLUSION}

The system of high performance liquid chromatography for selective and sensitive separation of INH in rat plasma was a valid method by using C18 $(150 \mathrm{~mm}$ 
$\mathrm{x} 4,6 \mathrm{~mm}$ ) as stationary phase, hexane sulphonate 20 $\mathrm{mm}$ (pH 2.47)-methanol (65:35) as mobile phase, with flow rate of $1 \mathrm{~mL} / \mathrm{min}$, UV detector at $265 \mathrm{~nm}$, and Vit B6 as an internal standard ${ }^{(3)}$.

\section{ACKNOWLEDGEMENTS}

The authors are grateful for a research grant from the Ministry of Research, Technology and Higher Education of the Republic of Indonesia.

\section{REFERENCES}

1. Bhandari R, Kaur IP. A sensitive HPLC method for determination of isoniazid in rat plasma, brain, liver, and kidney, J Chromat Separation Techniq, 2012; 3(3). ISSN2157-7064 JCGST.

2. EMA (European Medicines Agency). 2012. Guideline on bioanalytical method validation. EMA/CHMP/ EWP/192217/2009.

3. FDA (Food Drug Administration). 2013. Guidance for industry bioanalytical method of validation; available from:www.fda.gov/cder/guidance/index.htm.

4. Madhavi R, Mohana KA, Shobha RG, Mounika D. Isoniazid: A Review of Analytical Methods. Asian J. Pharm. Ana.,2015; 5(1): 41-5.

5. Klein DJ, Boukouvala S, McDonagh EM, Shuldiner SR, Laurieri N, Thorn CF, Altman RB, Klein TE. PharmGKB summary: isoniazid pathway, pharmacokinetics. Pharmacogenet Genomics. 2016 September,2016; 26(9): 436-44.

6. Peloquin, C. Therapeutic drug monitoring: principles and applicationsin mycobacterial infections. Drug Ther, 1992; 22:31-6.

7. Segovia RM, Flores GP, Tirado JDT, Romirez XH, Perez MV, Moreno SR. Simultaneous HPLC determination of isoniazid and acetylisoniazid in plasma. Acta chromatograph,2007; 19:110-18.

8. Stella. 2011. Optimation and validation of analytical method of isoniazid and pyrazinamide in 4 fixed dosecombination (4FDC) Tablet and plasma in vitro by hidh performance liquid chromatography, FMIPA UI. Depok. Indonesia.

9. Thee S, Seddon JA, Donald PR, Seifart HI, Werely CJ, Hesseling AC, Rosenkranz B, Roll S, Magdorf K, Schaaf HS. 2011. Pharmacokinetics of isoniazid, rifampin, and pyrazinamide in children younger than two years of age with tuberculosis: evidence for implementation of revised world health organization recommendations. Antimic Agent and Chemotheraph. Dec 2011. American Society for Microbiology. $5560-7$.

10. Unsalam S, Sancar M, Clark M, Karagoz T, Izzettin FV, Rollas S. Therapeutic monitoring of isoniazid, pyrazinamide, and rifampisin in tuberculosis patients using LC. J Chromatogr., 2005; No 61.
11. WHO (World Health Organization). 2011. Child growth standards. WHO, Geneva, Switzerland. http: // www.who.int/childgrowth/standards/weight_for_age/ en/index.html. 